\title{
Persistence of Imidazolinones in Soils Under a Clearfield System of Rice Cultivation ${ }^{1}$
}

\author{
Persistência no Solo de Herbicidas Utilizados no Sistema Clearfield ${ }^{\circledR}$
}

\author{
SOUZA, M.F. ${ }^{2}$, NETO, M.D.C. ${ }^{3}$, MARINHO, M.I. ${ }^{2}$, SARAIVA, D.T. ${ }^{2}$, FARIA, A.T. ${ }^{2}$, SILVA, A.A. ${ }^{2}$, and \\ SILVA, D.V. ${ }^{4}$
}

\begin{abstract}
The commercial mixture of imazethapyr and imazapic herbicides has been used for the control of red rice and several other species of weeds found in rice crops; this system called Clearfield. However, its use may limit the succession of non-tolerant crops for long residual activity. The research objective with this work was to determine the persistence of imazethapyr, imazapic and their mixture in three soils in the Brazilian state of Tocantins. Three experiments were conducted in a completely randomized design with four replications, each corresponding to the evaluated soil (Haplic Plinthosol (FX), red-yellow Latosol (LVA) and Haplic Gleysol (GX)). The treatments were arranged in a split plot design, with the allocated plots herbicides (imazethapyr and imazapic alone and commercial mixture) and the plots allocated the 11 evaluation times $(1,15,30,45,60,75,90,105,120,135,150$ days after treatment (DAT)), and a control without application. Contacted up long residual effect of imazethapyr and commercial mixture of imazethapyr and imazapic, regardless of assessed soil. After 150 days of applying herbicides or the commercial mixture, their residues in the soil also inhibited approximately $94 \%$ of the mass of the dry matter accumulation of the indicator plants. When imazapic was applied alone, there was a higher dry matter accumulation of the indicator plants, indicating less residual effect of this herbicide in the soil and this was attributed to the lower dose of this herbicide applied. The attributes of the soil $\mathrm{pH}$, texture and iron oxides were what most affected the persistence of the herbicides. It can be concluded that the persistence of imazethapyr and imazapic is too long in the Brazilian state of Tocantins soils and the use of these herbicides in the region should be avoided due to the high risk of the occurrence of carryover,or be well planned, as land use in rotation for susceptible crops.
\end{abstract}

Keywords: carryover, imazapic, imazethapyr, only ${ }^{\mathbb{B}}$.

RESUMO - O sistema de cultivo Clearfield ${ }^{\circledR}$ utiliza os herbicidas imazethapyr e imazapic no controle de plantas daninhas. Um dos principais problemas relacionados ao uso desse sistema é a restrição ao cultivo de outras culturas, causada pelo efeito residual dos herbicidas. Três experimentos foram realizados para avaliar a persistência do imazethapyr e imazapic em solos utilizados no sistema Clearfield ${ }^{\circledR}$. Cada experimento correspondeu a um solo avaliado: Plintossolo Háplico, Latossolo Vermelho-Amarelo ou Gleissolo Háplico. $O$ imazethapyr e o imazapic isolados e em mistura comercial foram aplicados no solo, $e$ seu residual foi avaliado em 11 épocas (1, 15, 30, 45, 60, 75, 90, 105, 120, 135 e 150 dias após o tratamento). A planta indicadora utilizada foi o sorgo (Sorghum vulgare). $O$ imazethapyr e sua mistura com o imazapic causaram reduções da matéria seca das plantas indicadoras superiores a 94\%, mesmo após 150 dias da aplicação, independentemente do solo avaliado. O imazapic causou menor inibição do crescimento do sorgo, indicando menor efeito residual desse herbicida nos solos. A mistura comercial teve maior persistência, comparada à aplicação isolada dos herbicidas. Independentemente do tipo de solo, a persistência do imazethapyr foi maior que a do imazapic.

Palavras-chave: carryover, imazapic, imazethapyr, only ${ }^{\circledR}$.

Recebido para publicação em 15.10.2015 e aprovado em 12.1.2016.

2 Universidade Federal de Viçosa, Viçosa, Minas Gerais, Brasil; ${ }^{3}$ Instituto Federal de Educação, Ciência e Tecnologia do Tocantins, Gurupi, TO, Brasil; ${ }^{4}$ Universidade Federal Rural do Semi-Árido, Mossoró, Rio Grande do Norte, Brasil, <freitasouza@yahoo.com.br>. 


\section{INTRODUCTION}

Imazethapyr and imazapic are herbicides from the imidazolinones chemical group that act in the inhibition of the acetolactate synthase (ALS) enzyme and have an action in the control of weeds in postemergence in soybean crops and in preemergence and postemergence in peanut and sugarcane crops, respectively (Rodrigues \& Almeida, 2011). The commercial mixture of these herbicides has been widely used in crops resistant to imidazolinone cultivated in the Clearfield ${ }^{\circledR}$ Production System due mainly to the excellent control of troublesome weeds such as weedy rice (also known as red rice).

Although used in low doses, imazethapyr and imazapic can remain for long periods in the soil, which can cause agronomic and environmental problems (Kraemer et al., 2009). Herbicides with long residual effect exercise a prolonged weed control, but can cause poisoning in crops sown in succession and contaminate groundwater and water sources, either by leaching or surface runoff (Oliveira \& Brighenti, 2011).

Factors such as sorption, leaching, degradation, and/or biological transformation regulate the concentration and flow of herbicides in the soil, determining the persistence of these molecules (Oliveira Junior \& Regitano, 2009). Furthermore, the soil physical and chemical properties and the nature of the compound also directly influence the persistence of pesticides in the environment (Prata et al., 2003). The persistence of imidazolinones in the soil influences the $\mathrm{pH}$ (Aichele \& Penner, 2005), moisture (Baughman \& Shaw, 1996) and the soil organic matter content (Stougaard et al., 1990; Jourdan \& Ayeni, 1998). Overall, imazethapyr and imazapic suffer from limited biodegradation under anaerobic conditions (Senseman, 2007), which increases the persistence in hidromorphic soils and a residual effect on the susceptible rice may occur even after 12 months of application (Villa et al., 2006).

Knowledge of the persistence of imazethapyr and imazapic in tropical soils is important to improve the agronomic efficiency of herbicides and reduce the risk of environmental contamination. Thus, the objective of this study was to evaluate the persistence of herbicides imazethapyr and imazapic applied alone or in a commercial mixture in soils cultivated in the Clearfield ${ }^{\circledR}$ system.

\section{MATERIAL AND METHODS}

Three experiments were carried out in a greenhouse at the public, federal university of the state of Tocantins, in Brazil, Universidade Federal do Tocantins - UFT campus from November 2012 to January 2013. Each experiment corresponded to a type of soil studied: Haplic Plinthosol (FX), red-yellow Latosol (LVA) and Haplic Gleysol (GX), collected in the cities of Formoso do Araguaia, Gurupi and Lagoa da Confusão, respectively. All soil samples were collected at $0-20 \mathrm{~cm}$ depth, sieved through $4 \mathrm{~mm}$ meshes and subsequently characterized, chemically and physically, according to Empresa Brasileira de Pesquisa Agropecuária - Embrapa (1997) (Tables 1 and 2). Soil liming was not performed. To maintain good growth of the indicator plants, these were irrigated with a complete nutrient solution of Hoagland \& Arnon (1950).

The experiments were conducted in a completely randomized design with four replications. The treatments were arranged in a split plot design. The plot consisted of herbicides imazethapyr, imazapic and the commercial mixture (imazethapyr + imazapic) and the subplots by 11 sowing seasons of the bioindicator species $-1,15,30,45,60,75$, $90,105,120,135$ and 150 days after the treatment (DAT). A control without herbicide application was added. The accumulation of dry matter of the treatments was converted to a percentage relative to the control dry matter accumulation.

Plastic pots with a capacity of $0.33 \mathrm{dm}^{3}$ were filled with soil. Imazethapyr and imazapic, alone and in a commercial mixture in doses of 75 and $25 \mathrm{~g} \mathrm{ha}^{-1}$, respectively, were applied in the pots surface.

A pressurized sprayer at compressed $\mathrm{CO}_{2}$ was used, equipped with two nozzles TT11002, 
Table 1 - Chemical, physicochemical, and physical characteristics and sample texture of Haplic Plinthosol (FX), red-yellow Latosol (LVA) and Haplic Gleysol (GX) soils

\begin{tabular}{|c|c|c|c|c|c|c|c|c|c|c|}
\hline \multirow{2}{*}{ Soil } & \multirow{2}{*}{$\begin{array}{c}\mathrm{pH} \\
\left(\mathrm{H}_{2} \mathrm{O}\right)\end{array}$} & $\mathrm{P}$ & $\mathrm{K}$ & $\mathrm{Ca}^{2+}$ & $\mathrm{Mg}^{2+}$ & $\mathrm{Al}^{3+}$ & $\mathrm{H}+\mathrm{Al}$ & $(\mathrm{t})$ & $\mathrm{V}$ & $\mathrm{m}$ \\
\hline & & \multicolumn{2}{|c|}{$\left(\mathrm{mg} \mathrm{dm}^{-3}\right)$} & \multicolumn{5}{|c|}{$\left(\mathrm{cmol}_{\mathrm{c}} \mathrm{dm}^{-3}\right)$} & \multicolumn{2}{|c|}{$(\%)$} \\
\hline $\mathrm{FX}$ & 6.1 & 3.5 & 27 & 3.39 & 1.35 & 0.00 & 3.0 & 4.8 & 61.6 & 0.0 \\
\hline LVA & 5.7 & 0.8 & 79 & 0.99 & 0.52 & 0.00 & 4.7 & 1.7 & 26.7 & 0.0 \\
\hline \multirow[t]{3}{*}{ GX } & 5.2 & 1.3 & 82 & 1.69 & 0.75 & 0.57 & 5.2 & 3.2 & 33.8 & 17.7 \\
\hline & \multicolumn{3}{|c|}{ Ferrioxalate } & \multicolumn{4}{|c|}{ Ferrous dithionite } & \multicolumn{3}{|c|}{$\mathrm{OM}$} \\
\hline & \multicolumn{10}{|c|}{$\left(\right.$ dag kg $\left.^{-1}\right)$} \\
\hline $\mathrm{FX}$ & \multicolumn{3}{|c|}{0.10} & \multicolumn{4}{|c|}{1.29} & \multicolumn{3}{|c|}{2.22} \\
\hline LVA & \multicolumn{3}{|c|}{0.14} & \multicolumn{4}{|c|}{2.19} & \multicolumn{3}{|c|}{3.00} \\
\hline GX & \multicolumn{3}{|c|}{0.56} & \multicolumn{4}{|c|}{0.83} & \multicolumn{3}{|c|}{2.35} \\
\hline
\end{tabular}

Analyses carried out according to the methodology of Empresa Brasileira de Pesquisa Agropecuária (Brazilian Corporation of Agricultural Research) - Embrapa (1997).

Table 2 - Results of the physical analyses and texture classification of the Haplic Plinthosol (FX), red-yellow Latosol (LVA) and Haplic Gleysol (GX) soil samples

\begin{tabular}{|l|c|c|c|c|c|}
\hline \multirow{2}{*}{ Soil } & Coarse sand & Fine sand & Silt & Clay & \multirow{2}{*}{ Textural class } \\
\cline { 2 - 5 } & \multicolumn{4}{|c|}{$\left(\mathrm{dag} \mathrm{kg}^{-1}\right)$} \\
\hline FX & 17 & 30 & 16 & 37 & Clayey-sandy \\
\hline LVA & 32 & 23 & 6 & 39 & Clayey-sandy \\
\hline GX & 0 & 32 & 45 & 23 & Loam \\
\hline
\end{tabular}

Analyses carried out according to the methodology of Empresa Brasileira de Pesquisa Agropecuária (Brazilian Corporation of Agricultural Research) - Embrapa (1997).

spaced $0.50 \mathrm{~m}$, kept in pressure of $25 \mathrm{lb} \mathrm{pol}^{-2}$, with spray volume of $150 \mathrm{~L} \mathrm{ha}^{-1}$.

Sorghum (Sorghum vulgare), cultivar BRS 655, was used as an indicator plant of the herbicides. Soil moisture was maintained by means of daily watering, keeping the soil at field capacity. At 21 days after emergence (DAE) of sorghum, intoxication evaluations were held - visual scale ranging from 0 to 100 , where 0 means no symptom and 100 means plant death. Subsequently, the plants were cut close to the ground and wrapped in paper bags. These were taken to dry in an oven and then the plants dry matter was determined.

For interpretation of results, data were submitted to analysis of variance. For quantitative data, regression curves were generated, and for the qualitative data, the values of Significant Mean Difference (SMD) by the Tukey's test at $5 \%$ were introduced.

\section{RESULTS}

\section{Haplic Plinthosol (FX)}

The largest dry matter accumulation when applying imazapic from 75 DAA in relation to imazethapyr and the mixture is due to the decrease of the herbicide concentration in the soil solution (Figure 1, Table 3). This fact is probably related to the lower rate of application in relation to the commercial mixture and imazethapyr alone since the physicochemical characteristics of these molecules are similar. Research involving the persistence of imazapic with different application doses in a (clayey textured) Distroferric Red Latosol showed a high residual effect for this herbicide (Ulbrich et al., 2005).

The lower dry matter of sorghum at 135 and $150 \mathrm{DAA}$, when applied to the commercial mixture of imazethapyr and imazapic (Figure 1), is due to the low degradation of the 
Table 3 - Sorghum plant poisoning evaluated at 21 days after emergence (DAE) of seedlings sown at different times after the application of imazethapyr and imazapic alone and in a commercial mixture, in a Haplic Plinthosol (FX)

\begin{tabular}{|c|c|c|c|}
\hline \multirow{2}{*}{ DAE } & \multicolumn{3}{|c|}{ Herbicide } \\
\cline { 2 - 4 } & $\begin{array}{c}\text { Imazethapyr } \\
+ \text { imazapic } \\
\left(75+25 \mathrm{~g} \mathrm{ha}^{-1}\right)\end{array}$ & $\begin{array}{c}\text { Imazethapyr } \\
\left(75 \mathrm{~g} \mathrm{ha}^{-1}\right)\end{array}$ & $\begin{array}{c}\text { Imazapic } \\
\left(25 \mathrm{~g} \mathrm{ha}^{-1}\right)\end{array}$ \\
\cline { 2 - 4 } & \multicolumn{3}{|c|}{ Intoxication (\%) } \\
\hline 1 & 100.0 & 100.0 & 100.0 \\
\hline 15 & 100.0 & 100.0 & 100.0 \\
\hline 30 & 100.0 & 100.0 & 100.0 \\
\hline 45 & 100.0 & 100.0 & 100.0 \\
\hline 60 & 100.0 & 100.0 & 91.2 \\
\hline 75 & 98.7 & 98.7 & 80.0 \\
\hline 90 & 96.0 & 94.7 & 62.2 \\
\hline 105 & 93.2 & 88.2 & 53.5 \\
\hline 120 & 88.2 & 85.0 & 33.2 \\
\hline 135 & 87.0 & 83.2 & 26.7 \\
\hline 150 & 84.7 & 82.2 & 23.2 \\
\hline
\end{tabular}

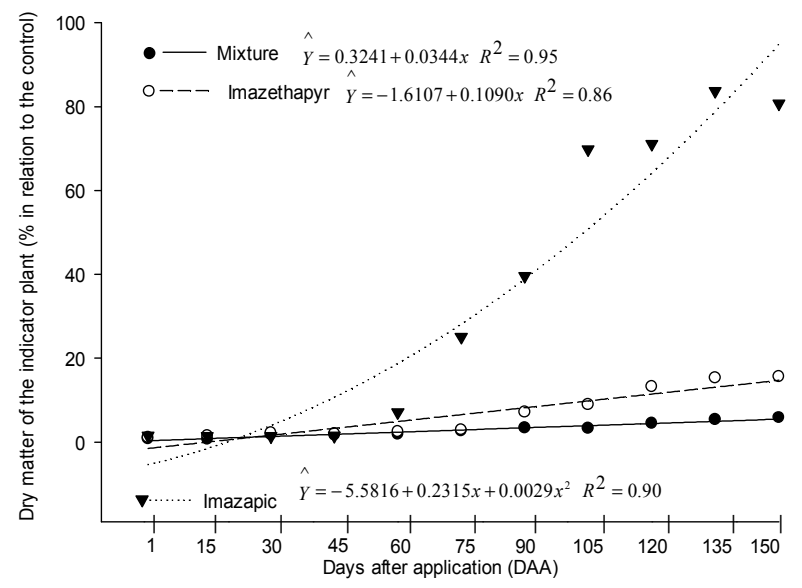

The vertical bar in each point represents the SMD (significant mean difference) of the Tukey's test, $\mathrm{p}<0.05$.

Figure 1 - Percentage of the shoots dry matter (SDM) of sorghum plants at 21 days after emergence of seedlings sown at different times after the application of imazethapyr and imazapic alone and in a commercial mixture, in a Haplic Plinthosol (FX).

herbicides in the soil. The degradation of the imidazolinones is characterized by being slow and continuous (Mangels, 1991). In addition to the characteristics of the molecule, another factor that may have contributed to the low degradation of these herbicides in the environment is their way of dissipation, which is associated with microbial degradation and photolytic decomposition (Wang et al., 2006; Espy et al., 2011).

The persistence of imazethapyr alone and in a commercial mixture is higher than the persistence of imazapic due to the fact that the persistence of the imidazolinone chemical group of herbicides is variable, depending on physical and chemical characteristics of the molecules, soil and climate conditions in the period between its use and sowing of non-tolerant plants (Kraemer et al., 2009). In addition, other factors such as dose increase (Silva et al., 1999), reduced pH (Tracy \& Penner, 2005) and the management adopted in the area (Sudo et al., 2002; Añasco et al., 2010) can also contribute to prolong the residual activity of imidazolinone group of herbicides. The dissipation of imazaquin, imazethapyr and imazamox decreases when the soil $\mathrm{pH}$ is reduced from 7.0 to 5.0 due to sorption increase, with consequent reduced bioavailability (Aichele \& Penner, 2005). Even in conditions of low sorption of the herbicide, its low degradation may occur due to the low microbial activity.

Imazapyr degradation in low microbial activity conditions may be 4.4 times slower in sterile soils compared to soils under natural conditions (Wang et al., 2005). Also, photolysis rates are slower due to the low penetration of light in the soil profile, especially in clayey textured soils (Balmer et al., 2000; Frank et al., 2002).

\section{Red-yellow Latosol (LVA)}

The lower dry matter values of sorghum from 90 DAA in the presence of imazapic alone is due to the higher persistence of the herbicide in LVA in relation to FX (Figures 1 and 2). This phenomenon may be associated with the lower $\mathrm{pH}$ value found in LVA when compared to FX. The weak acid character of the imazapic molecule coupled to soils with lower $\mathrm{pH}$ values increases the sorption of this herbicide in the soil. This fact is related to the greater presence of the herbicide molecules in the undissociated state, thus suffering less repulsion of the soil negative charges. Moreover, soils in more acidic $\mathrm{pH}$ acquire anion exchange capacity (AEC), increasing the interaction between the soil 
and the dissociated molecules of the herbicide. Once sorbed in the soil, the concentration of the herbicides in the solution thereof is lower, reducing the molecule degradation rate.

The reduction of dry matter (DM) of the sorghum plants and the high intoxication up to 75 days after application of herbicides imazethapyr and imazapic alone and in a mixture (Table 4, Figure 2 ) are due to the high persistence of these herbicides: above 150 DAA (Kraemer et al., 2009).

The residual effect in the soil of the imidazolinone group of herbicides can last up to two years (Renner et al., 1998) and, depending on the successor culture, cause phytotoxicity (Ball et al., 2003). Losses associated with residual imazethapyr and imazapic, alone or in a mixture, were reported in different cultures: alfalfa, cotton, rice, oats, rye, potato, canola, onions, sunflower, melon, maize, peppers, radishes, cabbage, sorghum, wheat and tomatoes (Bovey \& Senseman, 1998; Alister \& Kogan, 2005). These herbicides in the planting of non-resistant rice can reduce plant stand by residual effect from the application of the imazethapyr and imazapic mixture in previous harvests, but without effect on yield (Villa et al., 2006). A time interval of at least 18 months between the application and conventional rice sowing is suggested (Williams et al., 2002).

Table 4 - Sorghum plant poisoning evaluated at 21 days after emergence (DAE) of seedlings sown at different times after the application of imazethapyr and imazapic alone and in a commercial mixture, in a red-yellow Latosol (LVA)

\begin{tabular}{|c|c|c|c|}
\hline \multirow{3}{*}{ DAE } & \multicolumn{3}{|c|}{ Herbicide } \\
\hline & $\begin{array}{c}\text { Imazethapyr } \\
+ \text { imazapic } \\
\left(75+25 \mathrm{~g} \mathrm{ha}^{-1}\right)\end{array}$ & $\begin{array}{c}\text { Imazethapyr } \\
\left(75 \mathrm{~g} \mathrm{ha}^{-1}\right)\end{array}$ & $\begin{array}{l}\text { Imazapic } \\
\left(25 \mathrm{~g} \mathrm{ha}^{-1}\right)\end{array}$ \\
\hline & \multicolumn{3}{|c|}{ Intoxication (\%) } \\
\hline 1 & 100.0 & 100.0 & 100.0 \\
\hline 15 & 100.0 & 100.0 & 100.0 \\
\hline 30 & 100.0 & 100.0 & 100.0 \\
\hline 45 & 100.0 & 100.0 & 100.0 \\
\hline 60 & 100.0 & 98.7 & 97.5 \\
\hline 75 & 99.0 & 97.7 & 95.5 \\
\hline 90 & 97.2 & 96.2 & 86.2 \\
\hline 105 & 96.2 & 95.0 & 84.5 \\
\hline 120 & 96.0 & 85.7 & 69.7 \\
\hline 135 & 95.5 & 85.0 & 60.5 \\
\hline 150 & 90.0 & 83.0 & 57.0 \\
\hline
\end{tabular}

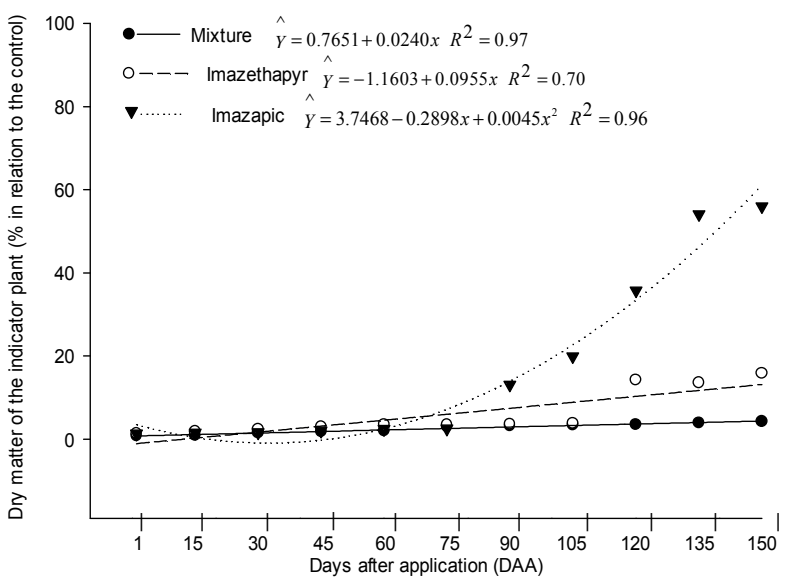

The vertical bar in each point represents the SMD (significant mean difference) of the Tukey's test, $\mathrm{p}<0.05$.

Figure 2 - Percentage of the shoots dry matter (SDM) of sorghum plants in relation to the control, assessed at 21 days after emergence of seedlings sown at different times after the application of imazethapyr and imazapic alone and in a commercial mixture, in a red-yellow Latosol (LVA).

\section{Haplic Gleysol (GX)}

The reduction in sorghum dry matter accumulation along the sowing times over $60 \%$ by imazethapyr and imazapic, alone or in a commercial mixture (Table 5, Figure 3 ), is due to the residual activity of the commercial mixture of these herbicides, which can reach 1100 days after application, reducing the DM of shoots in maize, cucumber, radish and tomato planted in soils containing residues of this mixture (Sousa et al., 2012). The imidazolinones, at $\mathrm{pH}$ greater than their $\mathrm{pKa}$, have a predominance of negative charges; imazethapyr and imazapic in highly weathered soils can interact with the positive portions of the organic matter, with metal cations and iron oxides, so as to remain sorbed by not returning easily to the soil solution, which would increase their persistence (Firmino et al., 2008). In clayey soils, sorption is attributed to the concentration of ferrioxalate and ferrous dithionite. In this circumstance, these features may also have contributed to the persistence of the imidazolinone group of herbicides in Haplic Gleysol (GX) in view of their relevant concentrations of ferrioxalate and ferrous dithionite. 
Table 5 - Sorghum plant poisoning evaluated at 21 days after emergence (DAE) of seedlings sown at different times after the application of imazethapyr and imazapic alone and in a commercial mixture, in a Haplic Gleysol (GX)

\begin{tabular}{|c|c|c|c|}
\hline \multirow{3}{*}{ DAE } & \multicolumn{3}{|c|}{ Herbicide } \\
\hline & $\begin{array}{c}\text { Imazethapyr } \\
+ \text { imazapic } \\
\left(75+25 \mathrm{~g} \mathrm{ha}^{-1}\right)\end{array}$ & $\begin{array}{l}\text { Imazethapyr } \\
\left(75 \mathrm{~g} \mathrm{ha}^{-1}\right)\end{array}$ & $\begin{array}{l}\text { Imazapic } \\
\left(25 \mathrm{~g} \mathrm{ha}^{-1}\right)\end{array}$ \\
\hline & \multicolumn{3}{|c|}{ Intoxication (\%) } \\
\hline 1 & 100.0 & 100.0 & 100.0 \\
\hline 15 & 100.0 & 100.0 & 100.0 \\
\hline 30 & 100.0 & 100.0 & 100.0 \\
\hline 45 & 100.0 & 100.0 & 100.0 \\
\hline 60 & 100.0 & 100.0 & 100.0 \\
\hline 75 & 100.0 & 100.0 & 97.0 \\
\hline 90 & 100.0 & 100.0 & 95.0 \\
\hline 105 & 100.0 & 100.0 & 90.0 \\
\hline 120 & 100.0 & 100.0 & 85.0 \\
\hline 135 & 100.0 & 100.0 & 80.0 \\
\hline 150 & 100.0 & 95.0 & 65.0 \\
\hline
\end{tabular}

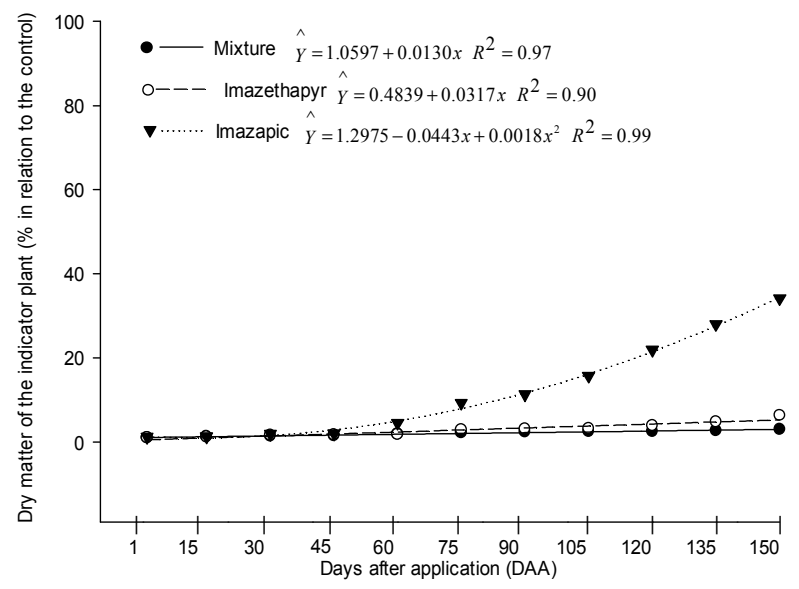

The vertical bar in each point represents the SMD (significant mean difference) of the Tukey's test, $\mathrm{p}<0.05$.

Figure 3 - Percentage of the shoots dry matter (SDM) of sorghum plants in relation to the control, assessed at 21 days after emergence of seedlings sown at different times after the application of imazethapyr and imazapic alone and in a commercial mixture, in a Haplic Gleysol (GX).

The high concentrations of the herbicides in soil at 45 days after application are due to factors associated with the sorption of the imidazolinone group of herbicides and how they affect the persistence of these molecules in the soil. Initially, the degradation of a molecule occurs when it is in the soil solution, and increased sorption of the herbicides to the colloids reduces its concentration. This could reduce the possibility of degradation of the molecule via microbial and/or photolytic decomposition (Tracy \& Penner, 2005).

Imazethapyr, in a mixture or alone, has kept a high reduction of the sorghum dry matter up to 150 DAA (Figure 3), while that for imazapic alone was only up to 60 DAA, which is due to the product lower dose effect: the imazapic applied dose is one fourth of the imazethapyr + imazapic dose. The persistence of imazethapyr and imazaquin in field conditions has a consistent effect of the dose on the half-life of the herbicides (Inoue et al., 2000). As for the dose effect on the persistence of imazethapyr, the application of $60 \mathrm{~g} \mathrm{ha}^{-1}$ was not sufficient to promote negative effects on the accumulation of DM of maize cultivated in succession with soybeans. However, the $100 \mathrm{~g} \mathrm{ha}^{-1}$ dose promoted a significant residual effect on maize (Dan et al., 2012). However, imidazolinones exhibit an amphoteric chemical nature, with two ionizable functional groups: a carboxylic group (acid) and an amino (basic); imazethapyr had an electrolytic dissociation capacity (pKA) of 3.9 in the carboxylic and 2.1 in the amino (Senseman, 2007). Imazethapyr and imazapic are predominantly found in the ionic form and the repulsion promoted by the soil negative charges increases the bioavailability of these herbicides in the soil solution (Loux et al., 1993).

This study has proven that herbicides imazethapyr and imazapic have long persistence in Haplic Gleysol (GX) and may remain in sufficient concentration to have a negative effect on dry matter accumulation of sensitive crop plants grown in succession to the main crop in the a time interval longer than 150 days after its application. Moreover, the results obtained in experiments with different soils - Haplic Plinthosol (FX), redyellow Latosol (LVA) and Haplic Gleysol (GX) show that the residual period of imazapic and imazethapyr in a commercial mixture is higher than when these herbicides are applied alone. It was also found that the persistence of these herbicides is dependent on the physical and chemical characteristics of each soil. In soils with lower $\mathrm{pH}$ values, imazethapyr and imazapic had higher persistence. The 
lower residual soil period of imazapic used alone in an application can be attributed to the lower dose of this herbicide.

It follows, from the results of experiments with different soils, that the residual period of the commercial mixture was greater than the herbicide application alone in all soils, followed by imazethapyr and imazapic. It was also found that the persistence of these herbicides is dependent on the physical and chemical characteristics of each soil. In soils with lower $\mathrm{pH}$ values, imazethapyr and imazapic had higher persistence. The lower residual soil period of imazapic used alone in an application can be attributed to the lower dose of this herbicide.

The application of imazethapyr and imazapic herbicides, alone or in combination, in the evaluated soils resulted in long residual effect. In addition, due to showing low sorption in the soils studied, coupled with long persistence in the conditions evaluated, applications of these herbicides represent a high risk of environmental contamination of soil and surface and groundwater, as well as the occurrence of carryover.

\section{ACKNOWLEDGMENTS}

The authors thank the "Higher Education Personnel Improvement Coordination" (Coordenação de Aperfeiçoamento de pessoal do Ensino Superior - CAPES, in portuguese), National Council for Scientific and Technological Development (Conselho Nacional de Desenvolvimento Científico e Tecnológico - CNPq, in portuguese), and the Minas Gerais State Research Foundation (Fundação de Amparo a Pesquisa do Estado de Minas Gerais - FAPEMIG, in portuguese) for their financial support and scholarships awarded.

\section{LITERATURE CITED}

AICHELE, T. M.; PENNER, D. Adsorption, desorption, and degradation of imidazolinones in soil. Weed Technol., v. 19, n. 1, p. 154-159, 2005.

ALISTER, C.; KOGAN, M. Efficacy of imidazolinone herbicides applied to imidazolinone-resistant maize and their carryover effect on rotational crops. Crop Protec., v. 24, n. 4, p. 375-379, 2005.
AÑASCO, N. C.; KOYAMA, J.; UNO, S. Pesticide residues in coastal waters affected by rice paddy effluents temporarily stored in a wastewater reservoir in southern Japan. Arch.

Environ. Contam. Toxicol., v. 58, n. 2, p. 352-360, 2010.

BALL, D. A.; YENISH, J. P.; ALBY, T. Effect of imazamox soil persistence on dryland rotation crops. Weed Technol., v. 17, n. 1, p. 161-165, 2003.

BALMER, M. E.; GOSS, K. U.; SCHARZENBACH, R. P. Photolytic transformation of organic pollutants on soil surfaces-an experimental approach. Environ. Sci. Technol., v. 34 , n. 7, p. $1240-1245,2000$.

BAUGHMAN, T. A.; SHAW, D. R. Effect of wetting/drying cycles on dissipation patterns of bioavailable imazaquin. Weed Sci., v. 44, n. 2, p. 380-382, 1996.

BOVEY, R. W.; SENSEMAN, S. A. Response of food and forage crops to soil-applied imazapyr. Weed Sci., v. 46, n. 5 , p. 614-617, 1998.

DAN, H. A. et al. Resíduos de herbicidas utilizados na cultura da soja sobre o milho cultivado em sucessão. R. Caatinga, v. 25 , n. 1, p. 86-91, 2012.

EMPRESA BRASILEIRA DE PESQUISA

AGROPECUÁRIA - EMBRAPA. Centro Nacional de Pesquisa de Solos. Manual de métodos de análise de solos. 2.ed. Rio de Janeiro: 1997. 212 p.

ESPY, R. et al. Photodegradation of the Herbicide Imazethapyr in Aqueous Solution: Effects of Wavelength, pH, and Natural Organic Matter (NOM) and analysis of photoproducts. J. Agric. Food Chem., v. 59, p. 7277-7285, 2011.

FIRMINO, L. E. et al. Movimento do herbicida imazapyr no perfil de solos tropicais. Planta Daninha, v. 26, n. 1, p. 223-230, 2008.

FRANK, M. P.; GRAEBING, P.; CHIB, J. S. Effect of soil moisture and sample depth on pesticide photolysis. J. Agric. Food Chem., v. 50, n. 9, p. 2607-2614, 2002.

HOAGLAND, D.; ARNON, D. I. The water culture method for growing plants without soil. Berkeley: California Agriculture Experimental Station, 1950. 347 p.

INOUE, M. H. et al. Persistência da atividade biológica de imazaquin e imazethapyr aplicados em duas épocas do ano. Acta Sci., v. 22, n. 4, p. 993-997, 2000.

JOURDAN, S. W.; AYENI, A. O. Imazethapyr bioactivity and movement in soil. Weed Sci., v. 46, n. 5, p. 608-613, 1998.

Planta Daninha, Viçosa-MG, v. 34, n. 3, p. 589-596, 2016 
KRAEMER, A. F. et al. Destino ambiental dos herbicidas do grupo das imidazolinonas. Planta Daninha, v. 27, n. 3, p. 629-639, 2009.

LOUX, M.; REESE, K. Effect of soil type and $\mathrm{pH}$ on persistence and carryover of imidazolinones herbicides. Weed Technol., v. 7, n. 2, p. 452-458, 1993.

MANGELS, G. Imazethapyr herbicides. In: SHANER, D.; CONNOR, S. (Ed.). The imidazolinones herbicides. Boca Raton: CRC Press, 1991. p. 191-209.

OLIVEIRA, M. F.; BRIGHENTI, A. M. Comportamento dos herbicidas no ambiente. In: OLIVEIRA JUNIOR, R. S.; CONSTANTI, J.; INOUE, M. H. Biologia e manejo de planta daninha. Curitiba: Omnipax, 2011. p. 264-304.

OLIVEIRA JUNIOR, R. S.; REGITANO, J. B. Dinâmica de pesticidas no solo. In: MELO, V. F.; ALLEONI, L. R. F. (Ed.). Química e mineralogia do solo: aplicações. Viçosa, MG: Sociedade Brasileira de Ciência do Solo, 2009. Pt 2. p. $187-248$.

PRATA, F. Glyphosate sorption and desorption in soils with distinct phosphorus levels. Sci. Agric., v. 60, n. 1, p. $175-180,2003$.

RENNER, K. A.; SCHABENBERGER, O.; KELLS, J. J. Effect of tillage an application method on corn (Zea mays) response to imidazolinone residues in soil. Weed Technol., v. 12, n. 2, p. 281-285, 1998.

RODRIGUES, B. N.; ALMEIDA, F. S. Guia de herbicidas. 6. ed. Londrina: 2011. 697 p.

SENSEMAN, S. A. (Ed.). Herbicide handbook. 9. ed. Lawrence: Weed Science Society of America, 2007. 458 p.

SILVA, A. A. et al. Persistência de herbicidas do grupo das imidazolinonas e efeitos sobre as culturas sucessoras de milho e sorgo. Acta Sci., v. 21, n. 3, p. 459-465, 1999.
SOUSA, C. P.; BACARIN, M. A.; PINTO, J. J. O. crescimento de espécies bioindicadoras do residual do herbicida (imazethapyr+ imazapic), semeadas em rotação com arroz Clearfield ${ }^{\circledR}$. Planta Daninha, v. 30, n. 1, p. 105-111, 2012.

STOUGAARD, R. N.; SHEA, P. J.; MARTIN, A. R. Effect of soil type and $\mathrm{pH}$ on adsorption, mobility and efficacy of imazaquin and imazethapyr. Weed Sci., v. 36, n. 1, p. 67-73, 1990.

SUDO, M.; KUNIMATSU, T; OKUBO, T. Concentration and loading of pesticide residues in Lake Biwa basin (Japan). Water Res., v. 36, n. 1, p. 315-329, 2002.

TRACY, M. A.; PENNER, D. Adsorption, desorption, and degradation of imidazolinones in soil. Weed Technol., v. 19, n. 1, p. 154-159. 2005.

ULBRICH, A. V.; SOUZA, J. R. P.; SHANER, D. Persistence and Carryover Effect of Imazapic and Imazapyr in Brazilian Cropping Systems1. Weed Technol., v. 19, p. 986-991, 2005.

VILLA, S. C. C. et al. Arroz tolerante a imidazolinonas: controle do arroz-vermelho, fluxo gênico e efeito residual do herbicida em culturas sucessoras não-tolerantes.

Planta Daninha, v. 24, n. 4, p. 761-768, 2006.

WANG, X.; WANG, H.; FAN, D. Degradation and metabolism of imazapyr in soils under aerobic and anaerobic conditions. Inter. J. Environ. Anal. Chem., v. 86, n. 8, p. 541-551, 2006.

WANG, X.; ZHOU, S. M.; FAN, D. Biodegradation of imazapyr in typical soils in Zhejiang Province, China. J. Environ. Sci., v. 17, n. 4, p. 593-597, 2005.

WILLIAMS, B. J.; STRAHAN, R.; WEBSTER, E. P. Weed management systems for Clearfield Rice. Louisiana Agric., v. 45, n. 3 , p. 16-17, 2002. 